\title{
Genetic diversity and phylogeny of rhizobia isolated from Caragana microphylla growing in desert soil in Ningxia, China
}

\author{
J. Dai ${ }^{1,2}$, X. Liu ${ }^{1,2}$ and Y. Wang ${ }^{1,2}$ \\ ${ }^{1}$ Key Laboratory of the Ministry of Education for the Conservation and \\ Utilization of Special Biological Resources of Western China, Ningxia, China \\ ${ }^{2}$ College of Life Science, Ningxia University, Yinchuan, Ningxia, China \\ Corresponding author: Y. Wang \\ E-mail: wyj@nxu.edu.cn / yujiongw@gmail.com
}

Genet. Mol. Res. 11 (3): 2683-2693 (2012)

Received January 10, 2012

Accepted May 25, 2012

Published June 25, 2012

DOI http://dx.doi.org/10.4238/2012.June.25.5

\begin{abstract}
Rhizobia are soil bacteria with the capacity to induce nitrogen-fixing nodules on the roots or stems of legume plants. A total of 40 bacterial isolates from the root nodules of Caragana microphylla growing in desert soil in Ningxia, China, were analyzed for genetic diversity and phylogenetic position. These isolates were classified into 7 types of $16 \mathrm{~S}$ ribosomal DNA (rDNA) using polymerase chain reaction-restriction fragment length polymorphism analysis. They were grouped into 4 clades, Rhizobium-Agrobacterium, Sinorhizobium, Phyllobacterium, and Bradyrhizobium, when the phylogenies of $16 \mathrm{~S}$ rDNA, recA, and $a t p D$ genes were applied. Phylogenetic analysis showed that the tree generated from the $16 \mathrm{~S}$ rDNA sequencing agreed with that produced from the recA and $a t p D$ genes. By analyzing phylogenetic relationship using the 3 loci, the isolates in the branches of Phyllobacterium and Sinorhizobium could be identified as $P$. brassicacearum and $S$. meliloti. The isolates in the branch of Rhizobium-Agrobacterium were the most abundant microsymbiont of $C$. microphylla and were designated $R$. leguminosarum, $R$. galegae, $R$. alamii, and $A$. tumefaciens. Two isolates with low sequence similarity
\end{abstract}


to the known species of Bradyrhizobium might be novel species in this genus.

Key words: Phylogeny; 16S ribosomal DNA; recA; atpD; Rhizobia; Caragana microphylla

\section{INTRODUCTION}

Rhizobia are soil bacteria capable of forming nodules and establishing symbiosis with the roots or stems of legumes plants. During the process of symbiotic association, rhizobia reduce free $\mathrm{N}_{2}$ to nitrogen compound ammonia that is a usable nitrogen resource for the plants. The capability of rhizobia to fix nitrogen has significantly reduced the dependence of agriculture on nitrogen fertilizers. The populations and variety of rhizobia represent a valuable bioresource for the exploitation of bacterial selection in attempts to find bacterial strains with desirable traits that maximize legume crop productivity (Binde et al., 2009). Therefore, investigations of the diversity, dynamics, and characteristics of rhizobia residing in soil have practical importance in both ecology and agriculture. Such studies not only facilitate the discovery of unknown rhizobia but also support research efforts aimed at selecting effective combinations of Rhizobium-legume genotypes to exploit the enormous potential of increased nitrogen fixation. Owing to the ecological and economic importance of these microorganisms, their diversity and taxonomy have been extensively investigated during the last 2 decades. To date, more than 70 species of rhizobia from 11 genera in the $\alpha$-Proteobacteria (including Agrobacterium, Allorhizobium, Azorhizobium, Bradyrhizobium, Devosia, Mesorhizobium, Methylobacterium, Ochrobactrum, Phyllobacterium, Rhizobium, and Sinorhizobium/Ensifer) as well as Burkholderia, Cupriavidus, and Herbaspirillum in the $\beta$-Proteobacteria have been reported (Chen et al., 2003; Wang et al., 2006; Willems, 2006; Chen et al., 2008; Muresu et al., 2008). More than 19,700 species of leguminous plants occur throughout the world, but the microsymbionts of only a few have been investigated (Allen, 1981). As more leguminous species in divergent geographical regions are surveyed, more novel rhizobial species may be discovered.

Caragana microphylla, a species of the subfamily Papilionoideae in Leguminosae, is a perennial leguminous shrub that is highly tolerant to drought, salt, and extreme cold in relatively poor or sandy, well-drained soil. It is often used as a windbreak to protect soil from desertification. It is also used as forage for livestock and high-energy firewood in the northern regions of China. The flowers of this plant are an excellent food source for bees, and the seeds can be used as a component of herbal medicines (Yan et al., 2007). A growing body of evidence has focused on the exploration of Caragana plants for pharmaceutical compounds and bioremediation potential. However, few studies have focused on the symbiotic characteristics of the plant (Tan et al., 1999; Gao et al., 2002; Yan et al., 2007).

Symbiotic association between rhizobia and legumes plants might be affected by environmental factors. A recent study has shown that rhizobia species are abundant in drought areas in northwest China (Wei et al., 2008). Ningxia is a geographic region with typical features of an arid, semi-arid, and low rainfall area with very high evaporation potential. The soils in this area are poor in organic matter with high salinity and alkalinity. Considering the ecological importance of C. microphylla and the lack of information about its microsymbionts, systematic study of the relationship of rhizobia and legumes plants is essential. To this end, the genetic diversity and phylogenetic relationship of rhizobia associated with C. microphylla 
grown in the desertification grassland of the Ningxia Hui Autonomous Region were analyzed in this study using methods of $16 \mathrm{~S}$ ribosomal DNA (rDNA) restriction fragment length polymorphism (RFLP) and sequencing analysis of $16 \mathrm{~S}$ rDNA, atpD, and recA genes.

\section{MATERIAL AND METHODS}

\section{Bacterial isolation from root nodules of $C$. microphylla}

Fresh root nodules were collected from C. microphylla growing in the Baijitan National Nature Reserve of Ningxia. This region is a typical desert in the south rim of the Maowusu sandland $\left(106^{\circ} 20^{\prime}-106^{\circ} 37^{\prime} \mathrm{E}, 37^{\circ} 49^{\prime}-38^{\circ} 20^{\prime} \mathrm{N}\right)$. The surfaces of collected nodules were first sterilized with $75 \%$ ethanol and $0.1 \% \mathrm{HgCl}_{2}$ for 3 min each, then extensively rinsed several times with sterile distilled water before being crushed. The exudate of the crushed nodules was cultured on yeast-mannitol agar (YMA) medium at $28^{\circ} \mathrm{C}$ for 3-5 days, and a single colony was selected for further culture (Vincent, 1970). To confirm that the sterilization process was successful, we tested the water from the final rinse for bacterial growth in YMA medium. The purity of the culture was validated by repeated streaking on YMA medium and microscopic examination and identification of cellular morphology. All isolates were incubated on YMA slants at $28^{\circ} \mathrm{C}$ and maintained at $4^{\circ} \mathrm{C}$ for temporary storage or in $20 \%$ glycerol at $-70^{\circ} \mathrm{C}$ for long-term storage. A total of 40 individual bacterial isolates from 120 nodules of 40 plants were analyzed in this study (Table 1).

\section{DNA extraction and 16S rDNA PCR-RFLP}

Isolated bacteria were cultured in YMA liquid medium at $28^{\circ} \mathrm{C}$ for $48-72 \mathrm{~h}$, and the cells were collected by centrifugation at $10,000 \mathrm{rpm}$ at $4^{\circ} \mathrm{C}$ for $10 \mathrm{~min}$. Total genomic DNA of each strain was extracted as described elsewhere (Menna et al., 2006). Universal primers corresponding to Escherichia coli 16S rDNA positions 8-27 and 1492-1509 (Weisburg et al., 1991) were used to amplify 16S rDNA using PCR (Table 2). The PCR products were digested with restriction endonucleases MspI, HaeIII, and HinfI (Takara Biotech, Japan) as recommended elsewhere (Laguerre et al., 1994). The resulting fragments were resolved with electrophoresis on $2.5 \%(\mathrm{w} / \mathrm{v})$ agarose gels. The RFLP patterns obtained from the digestion were combined and used in cluster analysis with the Gelcompar II software package (Vauterin and Vauterin, 1992). Isolates that had identical RFLP patterns were regarded as the same 16S rDNA type. The PCR products of $16 \mathrm{~S}$ rDNA were confirmed through sequencing.

\section{Sequencing and phylogenetic analyses of $16 \mathrm{~S} \operatorname{rDNA}, \operatorname{rec} A$, and $a t p D$ genes}

The atpD and recA genes of representative strains from the seven 16S rDNA types were amplified according to a previously described method (Vinuesa et al., 2005). The parameters and primers for the amplification of recA and $a t p D$ are listed in Table 1. The PCR products were further sequenced on an ABI 3730 DNA sequencer at Sangon Biotech Co., Ltd. (Shanghai, China). The acquired $16 \mathrm{~S}$ rDNA, recA, and $a t p D$ gene sequences were then blasted in the GenBank database (http://www.ncbi.nlm.nih.gov/) to find similar sequences and were further aligned with CLUSTAL X1.8 (Thompson et al., 1997). Phylogenetic trees were constructed with the neighbor-joining method using Molecular Evolutionary Genetics Analysis 4.0 (Tamura et al., 2007). Statistical significance levels of interior nodes were determined via 
bootstrap with 1000 replications of each sequence.

\section{RESULTS}

\section{PCR-RFLP and sequence analysis of 16S rDNA}

All isolates were amplified an 1500 bp of single band using a 16S rDNA primer set, and the size of the amplicon was in agreement with the expected size of the 16S rDNA among bacteria as reported elsewhere (Weisburg et al., 1991). Seven rDNA types were identified among the 40 tested strains based on the results of the 16S rDNA PCR-RFLP patterns (see Table 1). Types 2 and 5 were the major groups, representing 30 and $22.5 \%$ of the isolates, respectively. To elucidate the phylogenetic relationships of the isolates further, 1 isolate from each rDNA type was selected for additional analysis by sequencing the entire 16S rDNA sequence ( 7 total isolates were selected). The phylogenetic tree is presented in Figure 1. The result indicated that all of the isolates could be grouped into 4 clades corresponding to Rhizobium-Agrobacterium, Sinorhizobium, Phyllobacterium, and Bradyrhizobium. Types 1 and 3 rDNA formed the Phyllobacterium clade, and the representative isolate CNXE1 shared 100, 97, and 97\% rDNA similarity to $P$. brassicacearum, $P$. myrsinacearum, and $P$. bourgognense, respectively. Types 2-5 rDNA consisted of the Rhizobium-Agrobacterium clades, which contained 30 isolates. Their representative strains had identical 16S rDNA sequences and shared 100, 100, 99, and 100\% rDNA similarity to $R$. leguminosarum, $R$. galegae, $R$. alamii, and $A$. tumefaciens, respectively. Type 6 rDNA represented the Bradyrhizobium clade; isolate CNX211 was identical to Bradyrhizobium sp and they shared $99 \%$ similarity of $16 \mathrm{~S}$ rDNA sequences. However, CNX211 shared only $92 \%$ sequence similarity to B. japonicum and B. yuanmingense. The isolates in rDNA type 7 belonged to the Sinorhizobium clade, which contained 5 isolates. The isolate CNXC3 shared $100 \%$ sequence similarity to $S$. meliloti and $99 \%$ to S. medicae, S. fredii, and S. xingjiangensis.

\begin{tabular}{|c|c|c|c|c|}
\hline \multirow[t]{2}{*}{ Isolates } & \multirow[t]{2}{*}{ rDNA type } & \multicolumn{3}{|c|}{ NCBI closest match (Sequence similarity \%) } \\
\hline & & 16S rDNA & $\operatorname{rec} A$ & atpD \\
\hline $\begin{array}{l}\mathrm{CNXE1}^{\dagger} \\
\text { CNXF1, CNXF2 }\end{array}$ & 1 & P. brassicacearum $(100 \%)$ & Phyllobacterium sp (89\%) & P. brassicacearum $(90 \%)$ \\
\hline $\begin{array}{l}\text { CNXLW24 } \\
\text { CNXE2, CNXE3, CNXE4, } \\
\text { CNXE5, CNXE7, CNXF5, } \\
\text { CNXF6, CNXF7, CNXF8, } \\
\text { CNXLW14, CNXLW20 }\end{array}$ & 2 & R. leguminosarum (100\%) & R. leguminosarum $(99 \%)$ & R. leguminosarum $(97 \%)$ \\
\hline $\begin{array}{l}\text { CNXE6 }^{\dagger} \\
\text { CNX053, CNX054 }\end{array}$ & 3 & R. galegae $(100 \%)$ & R. galegae $(97 \%)$ & R.. galegae $(99 \%)$ \\
\hline $\begin{array}{l}\mathrm{CNXF3}^{\dagger} \\
\text { CNXF4, CNXLW17, CNXC7, } \\
\text { CNXC8, CNXC10 }\end{array}$ & 4 & R. alamii $(100 \%)$ & R. alamii $(97 \%)$ & R. alamii $(95 \%)$ \\
\hline $\begin{array}{l}\mathrm{CNX}^{2} 404^{\dagger} \\
\text { CNX401, CNX402, CNX403, } \\
\text { CNX411, CNX412, CNX413, } \\
\text { CNX501, CNX502 }\end{array}$ & 5 & A. tumefaciens $(100 \%)$ & A. tumefaciens $(99 \%)$ & A. tumefaciens $(99 \%)$ \\
\hline $\begin{array}{l}\mathrm{CNX} 211^{\dagger} \\
\mathrm{CNX} 333\end{array}$ & 6 & Bradyrhizobium sp (99\%) & Bradyrhizobium sp (93\%) & Bradyrhizobium sp (93\%) \\
\hline $\begin{array}{l}\mathrm{CNXC}^{\dagger} \\
\text { CNXC1, CNXC2, } \\
\text { CNXC4, CNXC9 }\end{array}$ & 7 & S. meliloti $(100 \%)$ & S. meliloti $(98 \%)$ & S. meliloti $(98 \%)$ \\
\hline
\end{tabular}

$\uparrow$ Representative isolates used for sequencing and phylogenetic analysis. 


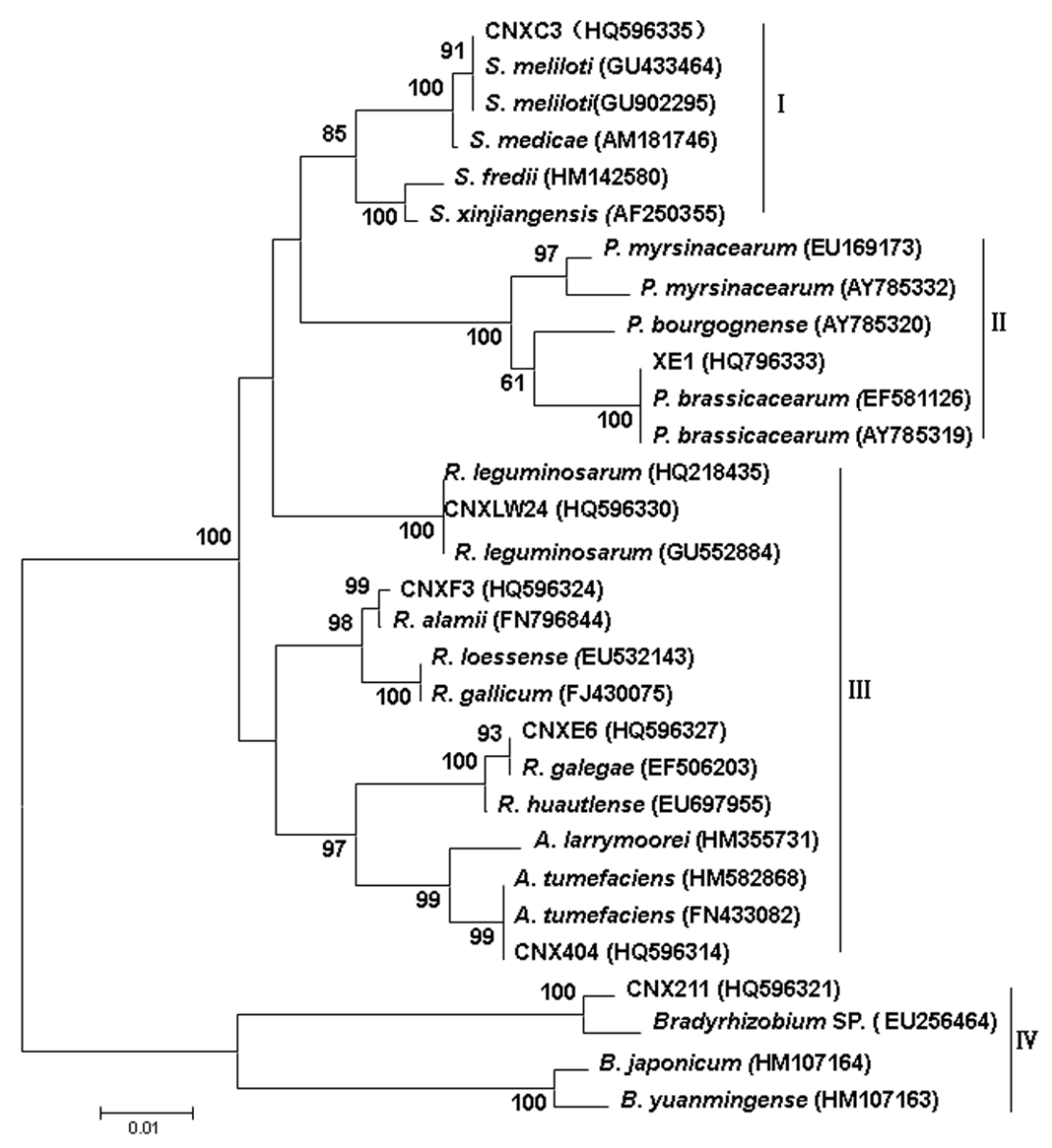

Figure 1. Phylogenetic trees generated with the $16 \mathrm{~S}$ rDNA gene sequence. Dendrogram shows the relationships of rhizobial isolates from Caragana microphylia root nodules to reference nodule bacteria. The clading pattern was produced by the neighbor-joining method. Numbers at nodes indicate levels of bootstrap support and were based on neighbor-joining analysis of 1000 resampled datasets. Bootstrap confidence levels greater than or equal to $60 \%$ are indicated at internodes. Scale bar indicates number of substitutions per site.

\section{Phylogenetic analyses of the $\operatorname{rec} A$ and $a t p D$ genes}

The recA gene encodes some of the proteins of the DNA recombination and repair system (Lloyd and Sharp, 1993; Cox, 2003), and numerous phylogenies of $r e c A$ in the bacteria are consistent with the corresponding 16S rDNA phylogenies (Gaunt et al., 2001; Ghosh and Roy, 2006; Martens et al., 2007). The atpD gene is a ubiquitous and conserved gene encoding the beta subunit of membrane ATP synthase, which is essential for energy production (Gaunt et al., 2001). The phylogenies of the recA and $a t p D$ genes were very similar to that of $16 \mathrm{~S}$ rDNA, with well-supported clades for Rhizobium-Agrobacterium, Sinorhizobium, Phyllobacterium, and Bradyrhizobium (Figures 2 and 3). The sequence similarities of the representative isolates are listed in Table 2. Isolate CNXE1 and the reference strains consisted of the Phyllo- 
bacterium clade, but they shared only $89 \%$ similarity of the recA gene sequence to Phyllobacterium sp and shared $90 \%$ atpD gene sequence similarity to $P$. brassicacearum. The sequences similarities of the recA and atpD genes between CNXE1 and other known species of the genus Phyllobacterium were less than $88 \%$. The representative strains of $16 \mathrm{~S}$ rDNA types $2-5$ CNXLW24, CNXE6, CNXF3, and CNX404 composing the Rhizobium-Agrobacterium clade shared 99, 97, 97, and 99\% recA gene sequence similarity to $R$. leguminosarum, $R$. galegae, $R$. alamii, and $A$. tumefaciens, respectively. The sequence similarities of the atpD gene in these representative strains to the above reference strains were $97,99,95$, and $99 \%$, respectively. The CNXC3 isolate had 98 and $91 \%$ recA and $a t p D$ gene sequence similarity to S. meliloti and $S$. meldicae, respectively. Isolate CNX211 shared $93 \%$ rec $A$ and $a t p D$ gene sequence similarity with Bradyrhizobium sp, and the similarities to B. yuanmingense, B. liaoningense, and $B$. japonicum were $85-88 \%$.

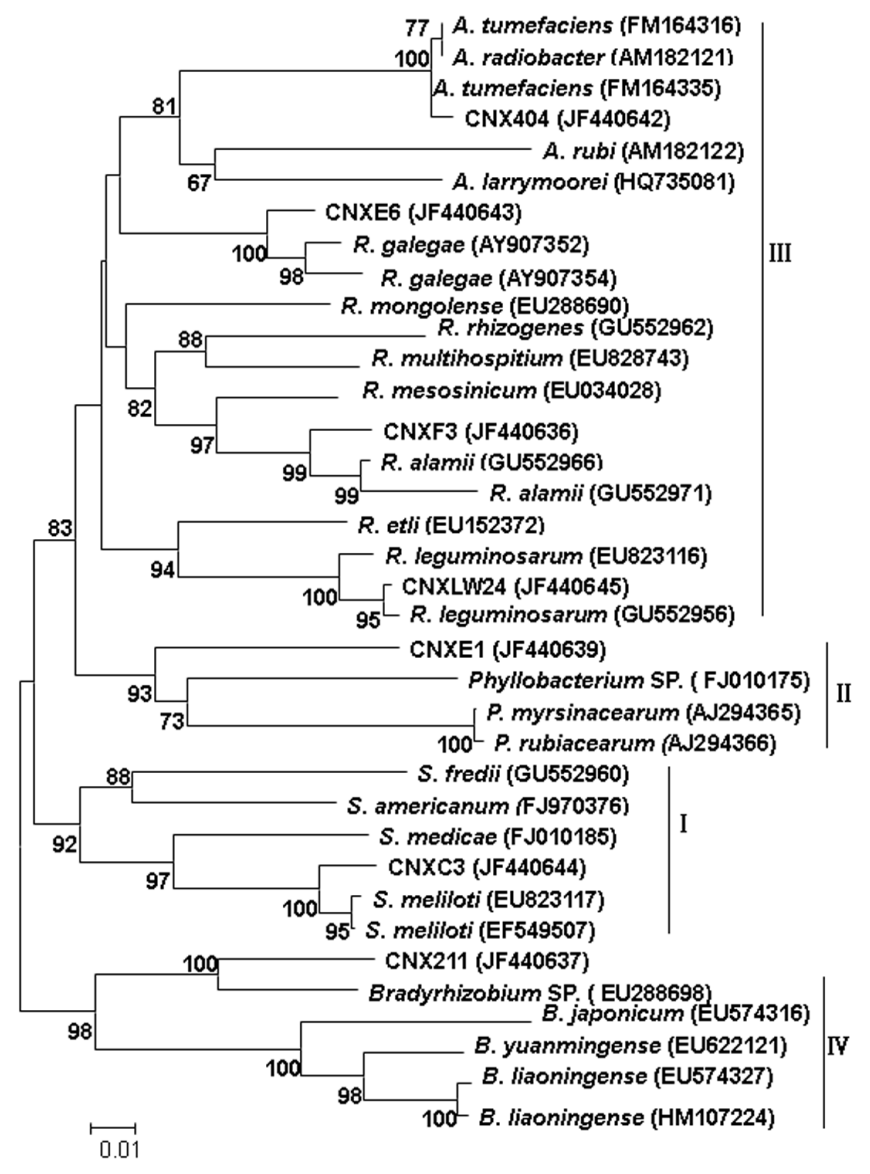

Figure 2. Phylogenetic trees generated with the recA gene sequence. Dendrogram shows the relationships of rhizobial isolates from Caragana microphylia root nodules to reference nodule bacteria. The clading pattern was produced by the neighbor-joining method. Numbers at nodes indicate levels of bootstrap support and were based on neighbor-joining analysis of 1000 resampled datasets. Bootstrap confidence levels greater than or equal to $60 \%$ are indicated at internodes. Scale bar indicates number of substitutions per site. 


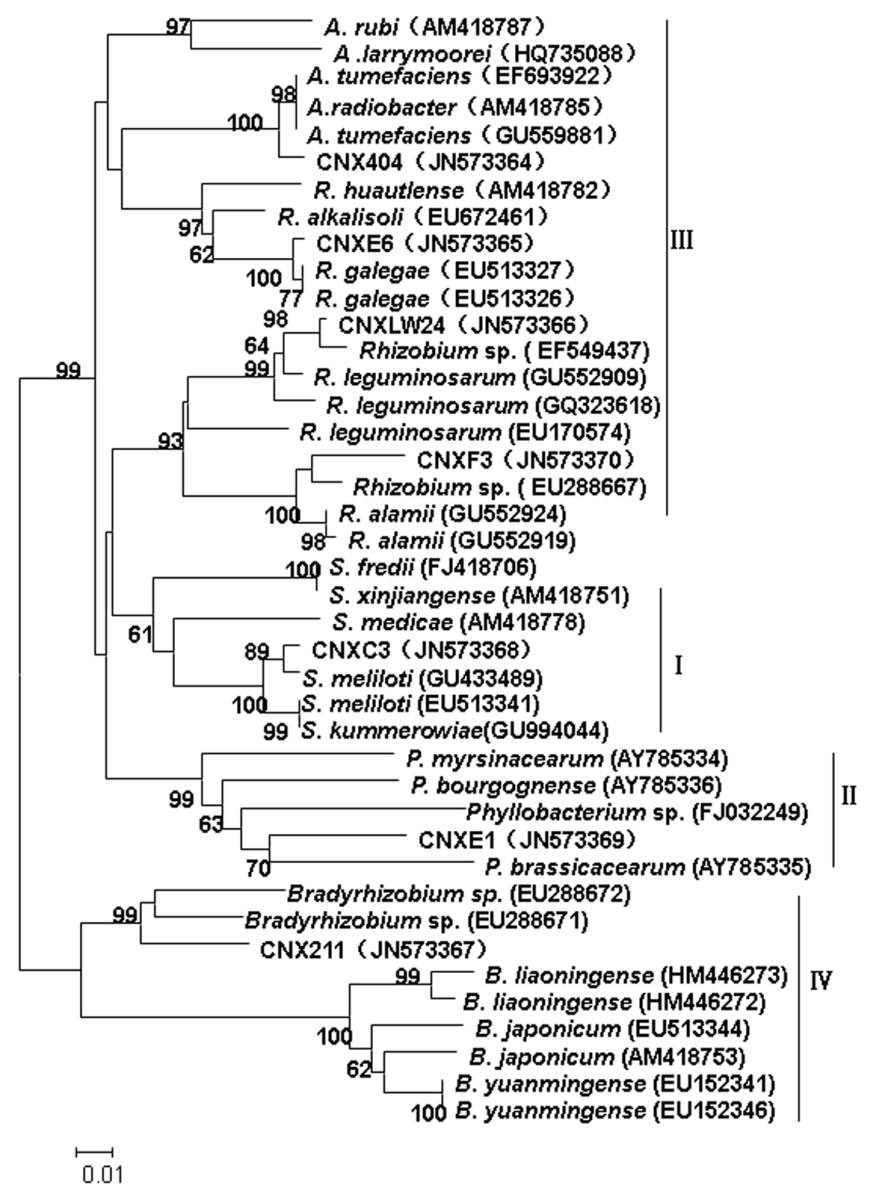

Figure 3. Phylogenetic trees generated with the $a t p D$ gene sequence. Dendrogram shows the relationships of rhizobial isolates from Caragana microphylia root nodules to reference nodule bacteria. The clading pattern was produced by the neighbor-joining method. Numbers at nodes indicate levels of bootstrap support and were based on neighbor-joining analysis of 1000 resampled datasets. Bootstrap confidence levels greater than or equal to $60 \%$ are indicated at internodes. Scale bar indicates number of substitutions per site.

Table 2. The parameters and primers of PCR.

\begin{tabular}{|c|c|c|c|c|}
\hline Primer & Sequence $\left(5^{\prime}-3^{\prime}\right)$ & PCR parameters ${ }^{\mathrm{a}}$ & Amplicon size (bp) & GenBank accession No. \\
\hline \multirow[t]{3}{*}{ 16s rDNA } & Forward: 5'-AGAGTTTGATCCTGGCTCAG-3' & $94^{\circ} \mathrm{C} 60 \mathrm{~s}$ & \multirow[t]{3}{*}{1500} & \multirow[t]{3}{*}{ AF041447 } \\
\hline & Reverse: 5'-TACGGYTACCTTGTTACGACTT-3' & $60^{\circ} \mathrm{C} 45 \mathrm{~s}$ & & \\
\hline & & $72^{\circ} \mathrm{C} 60 \mathrm{~s}$ & & \\
\hline \multirow[t]{3}{*}{ recA } & Forward: 5'-TTCGGCAAGGGMTCGRTSATG-3' & $94^{\circ} \mathrm{C} 60 \mathrm{~s}$ & \multirow[t]{3}{*}{500} & \multirow[t]{3}{*}{ AJ294376 } \\
\hline & Reverse: 5'-ACATSACRCCGATCTTCATGC-3' & $58^{\circ} \mathrm{C} 40 \mathrm{~s}$ & & \\
\hline & & $72^{\circ} \mathrm{C} 60 \mathrm{~s}$ & & \\
\hline \multirow[t]{3}{*}{$\operatorname{atp} D$} & Forward: 5'-ATCGGCGAGCCGGTCGACGA-3' & $94^{\circ} \mathrm{C} 60 \mathrm{~s}$ & \multirow[t]{3}{*}{470} & \multirow[t]{3}{*}{ AJ294405 } \\
\hline & Reverse: 5'-GCCGACACTTCCGAACCNGCCTG-3' & $58^{\circ} \mathrm{C} 40 \mathrm{~s}$ & & \\
\hline & & $72^{\circ} \mathrm{C} 60 \mathrm{~s}$ & & \\
\hline
\end{tabular}

a The reactions were incubated at $94^{\circ} \mathrm{C}$ for 4 min prior to amplification using the listed parameters for 30 thermal cycles. 


\section{Diversity of rhizobia isolates associated with $C$. microphylla}

Among the analyzed bacteria, 3 isolates were identified as Phyllobacterium and shared 100 and $90 \% 16 \mathrm{~S}$ rDNA and atpD sequence similarity, respectively, to P. brassicacearum. Systematic analysis of the phylogenetic relationship at these 3 loci further identified Phyllobacterium as $P$. brassicacearum. Most of the isolates belonged to Rhizobium, which were 16S rDNA types 2-4 (containing the 21 isolates listed in Table 2). These isolates had a high sequence identity at all 3 analyzed loci and shared the highest sequence similarity to $R$. leguminosarum, $R$. galegae, and $R$. alamii. Together, the sequencing results of $16 \mathrm{~S}$ rDNA and rec $A$ and atpD genes indicated they should be designated as $R$. leguminosarum, $R$. galegae, and $R$. alamii. Nine isolates of $16 \mathrm{~S}$ rDNA type 5 belonged to Agrobacterium, and their sequences were identical to that of $A$. tumefaciens. Five isolates from $16 \mathrm{~S}$ rDNA type 7 were grouped in Sinorhizobium. These strains were identified as $S$. meliloti based on their similarities to this bacterium in all analyzed categories.

\section{DISCUSSION}

In the present study, PCR-RFLP analysis of $16 \mathrm{~S}$ rDNA and phylogeny based on $16 \mathrm{~S}$ rDNA, $r e c A$, and $a t p D$ genes were used to analyze the genetic diversity of rhizobia isolates associated with $C$. microphylla growing in desert soil in Ningxia. The results demonstrated the genetic diversity and phylogeny of rhizobia in this region.

Studies of the diversity of rhizobia rely mainly on the analysis of 16S rDNA sequences for species-level identification. However, several studies have shown that 16S rDNA genes are capable of undergoing recombination and horizontal transfer that might result in sequence mosaicism (Eardly et al., 1996; Vinuesa et al., 2005). Another disadvantage of bacterial identification based on $16 \mathrm{~S}$ rDNA analysis is the difficulty in discriminating between closely related species owing to high levels of sequence conservation between these species (Acinas et al., 2004; Martens et al., 2007). Thus, a phylogenetic tree generated from a single locus may inadequately reflect the phylogenetic relationship of bacteria. The use of additional gene loci with great sequence divergence as well as sufficient conserved sequences for phylogenetic analysis may be an alternative approach that overcomes the drawbacks of $16 \mathrm{~S}$ rDNA analysis alone. For example, the use of a housekeeping protein encoding as a supplementary genetic marker has been introduced to identify rhizobia (Martens et al., 2007, 2008; Chen et al., 2008). Additional housekeeping genes including atpD, glnI, glnII, recA, and $d n a K$ have recently been used in taxonomic and phylogenetic studies of rhizobia (Gaunt et al., 2001; Naser et al., 2005; Vinuesa et al., 2005; Ghosh and Roy, 2006; Wang et al., 2007). Martens et al. (2008) have demonstrated that the sequencing of housekeeping genes is superior to DNA-DNA hybridization for the assessment of genetic relationships between species of the genus Ensifer.

A number of Agrobacterium strains isolated from root nodules of various legumes have been reported to lose nodulating capability with their host plants (Tan et al., 1999; Gao et al., 2004). One reasonable explanation is that they were never symbiotic but could invade nodules as endophytic bacteria (Wang et al., 2006). The group defined as S. meliloti has often been considered a rhizobial species with a host range limited to some species in the genera Medicago, Melilotus, and Trigonella (Szeto et al., 1984). However, a novel biovar of S. meliloti effectively nodulating Phaseolus vulgaris has been recently isolated in Africa (Mnasri et al., 2007), which might indicate that the 5 S. meliloti isolates identified as originating from $C$. 
microphylla in the present study enlarged the host range of S. meliloti. Despite 2 isolates having been previously identified as Bradyrhizobium, a common microsymbiont of many tropical legumes (Qian et al., 2003), their 16S rDNA similarities to all known species of the genus Bradyrhizobium were less than a "threshold" for species definition: 97\% (Stackebrandt and Goebel, 1994). Moreover, the sequence similarities of recA and atpD genes to B. yuanmingense, $B$. liaoningense, and $B$. japonicum were very low (85-88\%) as well. Therefore, these 2 isolates might represent novel species.

In this study, 40 rhizobia isolates originating from nodules of $C$. microphylla growing in desert soil in Ningxia, China, were classified into seven 16S rDNA types using PCR-RFLP and grouped into 4 clades-Rhizobium-Agrobacterium, Sinorhizobium, Phyllobacterium, and Bradyrhizobium-based on the phylogenies of $16 \mathrm{~S}$ rDNA, recA, and atpD genes. Most of these isolates $(21 ; 52 \%)$ belonged to the genus Rhizobium, and another $22.5 \%$ ( 9 isolates) were classified in the genus Agrobacterium. The other isolates were assigned to the genus Sinorhizobium (7 isolates), Phyllobacterium (7 isolates), and Bradyrhizobium (2 isolates).

These results differed from those of a previous report, in which agrobacteria-related strains were found to be the most abundant bacteria in the root nodules of Caragana intermedia growing in the Maowusu sandland (Inner Mongolia, China) (Gao et al., 2002), as well as a report that Mesorhizobium spp are the main microsymbionts of Caragana spp growing in the Liaoning Province of China (Yan et al., 2007). Caragana sp have the capability for stringent selection of rhizobia symbiotic genotype rather than genomic background, even though lateral transfer of symbiotic genes has been observed in Caragana rhizobia and their biogeography exhibit a clear correlation between rhizobial genospecies and eco-regions (Lu et al., 2009). Although the symbiotic association between rhizobia and leguminous plants is determined through molecular communication between the partners, it might be also affected by environmental factors. This hypothesis is supported by the fact that legume plants can nodulate with specific rhizobia in distinctive geographic regions, whereas various legume species in the same region might nodulate with the same rhizobial species-such as B. japonicum and Mesorhizobium plurifarium in tropical regions.

Furthermore, the effects of soil $\mathrm{pH}$ on the interaction between rhizobia and their legume hosts have been demonstrated (Yang et al., 2001), as have the effects of abiotic stress on the expression of nod genes (Duzan et al., 2004). Our results further confirmed the diversity of rhizobial populations or communities in a distinctive geographic region, suggesting that the symbiotic association between legumes and rhizobia is a result of interactions among rhizobia, legumes, and biogeographic and environmental factors.

The neighbor-joining tree generated in this study using $16 \mathrm{~S}$ rDNA was consistent with that generated with recA and $a t p D$ genes for the majority of the strains, although the precise branching patterns of various genes in some isolates were not in tight agreement with sequence trees produced with the 16S rDNA gene. For instance, the position of Phyllobacterium was ambiguous for each of the 3 genes. This result suggested that phylogenetic position can be influenced by the genes used for analysis, which is consistent with a finding that discordant phylogenies within different loci of rhizobia can result in different phylogenetic tree topologies for rhizobia species (van Berkum et al., 2003).

In conclusion, the results in this study demonstrated that $C$. microphylla growing in desert soil of Ningxia nodulated with diverse rhizobia species, and the phylogenetic lineage Rhizobium-Agrobacterium was the most abundant microsymbiont. These data offer new in- 
formation about the Caragana-rhizobia association in general and the genetic diversity and phylogeny of symbiotic legume rhizobia in desert soil in particular. Further studies of the correlation of rhizobia, host plant, and environmental factors are required.

\title{
ACKNOWLEDGMENTS
}

\author{
Research supported by a grant from the Ningxia Natural Fund Project.
}

\section{REFERENCES}

Acinas SG, Klepac-Ceraj V, Hunt DE, Pharino C, et al. (2004). Fine-scale phylogenetic architecture of a complex bacterial community. Nature 430: 551-554.

Allen EK (1981). The Leguminosae, A Source Book of Characteristics, Uses, and Nodulation. University of Wisconsin Press.

Binde DR, Menna P, Bangel EV, Barcellos FG, et al. (2009). rep-PCR fingerprinting and taxonomy based on the sequencing of the 16S rRNA gene of 54 elite commercial rhizobial strains. Appl. Microbiol. Biotechnol. 83: 897-908.

Chen WF, Guan SH, Zhao CT, Yan XR, et al. (2008). Different Mesorhizobium species associated with Caragana carry similar symbiotic genes and have common host ranges. FEMS Microbiol. Lett. 283: 203-209.

Chen WM, Moulin L, Bontemps C, Vandamme P, et al. (2003). Legume symbiotic nitrogen fixation by beta-proteobacteria is widespread in nature. J. Bacteriol. 185: 7266-7272.

Cox MM (2003). The bacterial RecA protein as a motor protein. Annu. Rev. Microbiol. 57: 551-577.

Duzan HM, Zhou X, Souleimanov A and Smith DL (2004). Perception of Bradyrhizobium japonicum Nod factor by soybean [Glycine $\max ($ L.) Merr.] root hairs under abiotic stress conditions. J. Exp. Bot. 55: 2641-2646.

Eardly BD, Wang F-S and Berkum P (1996). Corresponding 16S rRNA gene segments in Rhizobiaceae and Aeromonas yield discordant phylogenies. Plant Soil 186: 69-74.

Gao JL, Turner SL and Kan FL (2004). Mesorhizobium septentrionale sp. nov. and Mesorhizobium temperatum sp. nov., isolated from Astragalus adsurgens growing in the northern regions of China. Int. J. Syst. Evol. Microbiol. 54: 20032012.

Gao LF, Hu ZA and Wang HX (2002). Genetic diversity of rhizobia isolated from Caragana intermedia in Maowusu sandland, north of China. Lett. Appl. Microbiol. 35: 347-352.

Gaunt MW, Turner SL, Rigottier-Gois L, Lloyd-Macgilp SA, et al. (2001). Phylogenies of atpD and recA support the small subunit rRNA-based classification of rhizobia. Int. J. Syst. Evol. Microbiol. 51: 2037-2048.

Ghosh W and Roy P (2006). Mesorhizobium thiogangeticum sp. nov., a novel sulfur-oxidizing chemolithoautotroph from rhizosphere soil of an Indian tropical leguminous plant. Int. J. Syst. Evol. Microbiol. 56: 91-97.

Laguerre G, Allard MR, Revoy F and Amarger N (1994). Rapid identification of rhizobia by restriction fragment length polymorphism analysis of PCR-amplified 16S rRNA genes. Appl. Environ. Microbiol. 60: 56-63.

Lloyd AT and Sharp PM (1993). Evolution of the recA gene and the molecular phylogeny of bacteria. J. Mol. Evol. 37 : 399-407.

Lu YL, Chen WF, Wang ET, Guan SH, et al. (2009). Genetic diversity and biogeography of rhizobia associated with Caragana species in three ecological regions of China. Syst. Appl. Microbiol. 32: 351-361.

Martens M, Delaere M, Coopman R, De Vos P, et al. (2007). Multilocus sequence analysis of Ensifer and related taxa. Int. J. Syst. Evol. Microbiol. 57: 489-503.

Martens M, Dawyndt P, Coopman R, Gillis M, et al. (2008). Advantages of multilocus sequence analysis for taxonomic studies: a case study using 10 housekeeping genes in the genus Ensifer (including former Sinorhizobium). Int. J. Syst. Evol. Microbiol. 58: 200-214.

Menna P, Hungria M, Barcellos FG, Bangel EV, et al. (2006). Molecular phylogeny based on the 16S rRNA gene of elite rhizobial strains used in Brazilian commercial inoculants. Syst. Appl. Microbiol. 29: 315-332.

Mnasri B, Mrabet M, Laguerre G, Aouani ME, et al. (2007). Salt-tolerant rhizobia isolated from a Tunisian oasis that are highly effective for symbiotic $\mathrm{N}_{2}$-fixation with Phaseolus vulgaris constitute a novel biovar (bv. mediterranense) of Sinorhizobium meliloti. Arch. Microbiol. 187: 79-85.

Muresu R, Polone E, Sulas L, Baldan B, et al. (2008). Coexistence of predominantly nonculturable rhizobia with diverse, endophytic bacterial taxa within nodules of wild legumes. FEMS Microbiol. Ecol. 63: 383-400.

Naser SM, Thompson FL, Hoste B, Gevers D, et al. (2005). Application of multilocus sequence analysis (MLSA) for rapid

Genetics and Molecular Research 11 (3): 2683-2693 (2012)

CFUNPEC-RP www.funpecrp.com.br 
identification of Enterococcus species based on rpoA and pheS genes. Microbiology 151: 2141-2150.

Qian J, Kwon SW and Parker MA (2003). rRNA and nifD phylogeny of Bradyrhizobium from sites across the Pacific Basin. FEMS Microbiol. Lett. 219: 159-165.

Stackebrandt E and Goebel BM (1994). Taxonomic note: a place for DNA-DNA reassociation and 16S rRNA sequence analysis in the present species definition in bacteriology. Int. J. Syst. Bacteriol. 44: 846-849.

Szeto WW, Zimmerman JL, Sundaresan V and Ausubel FM (1984). A Rhizobium meliloti symbiotic regulatory gene. Cell 36: 1035-1043.

Tamura K, Dudley J, Nei M and Kumar S (2007). MEGA4: Molecular Evolutionary Genetics Analysis (MEGA) software version 4.0. Mol. Biol. Evol. 24: 1596-1599.

Tan ZY, Wang ET, Peng GX, Zhu ME, et al. (1999). Characterization of bacteria isolated from wild legumes in the northwestern regions of China. Int. J. Syst. Bacteriol. 49 Pt 4: 1457-1469.

Thompson JD, Gibson TJ, Plewniak F, Jeanmougin F, et al. (1997). The CLUSTAL_X windows interface: flexible strategies for multiple sequence alignment aided by quality analysis tools. Nucleic Acids Res. 25: 4876-4882.

van Berkum P, Terefework Z, Paulin L, Suomalainen S, et al. (2003). Discordant phylogenies within the rrn loci of Rhizobia. J. Bacteriol. 185: 2988-2998.

Vauterin L and Vauterin P (1992). Computer-aided objective comparison of electrophoresis patterns for grouping and identification of microorganisms. Eur. Microbiol. 1: 37-41.

Vincent J (1970). A Manual for the Practical Study of the Root-Nodule Bacteria. International Biological Programme, Londres.

Vinuesa P, Silva C, Lorite MJ, Izaguirre-Mayoral ML, et al. (2005). Molecular systematics of rhizobia based on maximum likelihood and Bayesian phylogenies inferred from rrs, atpD, recA and nifH sequences, and their use in the classification of Sesbania microsymbionts from Venezuelan wetlands. Syst. Appl. Microbiol. 28: 702-716.

Wang FQ, Wang ET, Liu J, Chen Q, et al. (2007). Mesorhizobium albiziae sp. nov., a novel bacterium that nodulates Albizia kalkora in a subtropical region of China. Int. J. Syst. Evol. Microbiol. 57: 1192-1199.

Wang LL, Wang ET, Liu J, Li Y, et al. (2006). Endophytic occupation of root nodules and roots of Melilotus dentatus by Agrobacterium tumefaciens. Microb. Ecol. 52: 436-443.

Wei GH, Zhang ZX, Chen C, Chen WM, et al. (2008). Phenotypic and genetic diversity of rhizobia isolated from nodules of the legume genera Astragalus, Lespedeza and Hedysarum in northwestern China. Microbiol. Res. 163: 651-662.

Weisburg WG, Barns SM, Pelletier DA and Lane DJ (1991). 16S ribosomal DNA amplification for phylogenetic study. J. Bacteriol. 173: 697-703.

Willems A (2006). The taxonomy of rhizobia: an overview. Plant Soil 287: 3-14.

Yan XR, Chen WF, Fu JF, Lu YL, et al. (2007). Mesorhizobium spp. are the main microsymbionts of Caragana spp. grown in Liaoning Province of China. FEMS Microbiol. Lett. 271: 265-273.

Yang SS, Bellogin RA, Buendia A, Camacho M, et al. (2001). Effect of pH and soybean cultivars on the quantitative analyses of soybean rhizobia populations. J. Biotechnol. 91: 243-255. 